\title{
Characteristics of Absorption and Accumulation of Inorganic Germanium in Panax ginseng C. A. Meyer
}

\author{
Je-Yong Kang ${ }^{{ }^{*}}$, Chan-Soo Park ${ }^{1}$, Sung-Ryong Ko ${ }^{1}$, Kyo In $^{1}$, Chol-Soo Park ${ }^{1}$, Dong-Yun Lee ${ }^{1}$, and \\ Deok-Chun Yang ${ }^{2}$
}

${ }^{1}$ Research Institute, Korea Ginseng Corporation, Daejeon 305-805, Korea

${ }^{2}$ Department of Oriental Medicinal Materials and Processing, Kyung Hee University, Suwon 449-701, Korea

The characterstics of absorption and accumulation of inorganic germanium in Panax ginseng C. A. Meyer were examined. In 4-year-old $P$. ginseng, the germanium content of the field soil increased with increased amounts and frequencies of inorganic germanium application, while chemical components of the soil, such as available phosphate and exchangeable calcium, potassium, and magnesium, decreased with the increased inorganic germanium application. In the 4-year-old $P$. ginseng, the germanium content was highest in the rhizome and increased in the order of stem, leaf, lateral root, and main root, suggesting that inorganic germanium was absorbed from the root and translocated to the stem and leaf via the rhizome. As for changes in ginsenosides in 4-year-old $P$. ginseng rhizomes, the contents of ginsenosides $\mathrm{Rb}_{1}, \mathrm{Rb}_{2}$, Re, and $\mathrm{Rf}$ decreased as the germanium content in soil increased. Ginsenosides $\mathrm{Rb}_{1}, \mathrm{R} \mathrm{b}_{2}, \mathrm{Rc}$, Re, and $\mathrm{Rf}$ in the main root also decreased with increasing germanium content in the main root. The results suggest that inorganic germanium treatment may increase organic germanium in harvested $P$. ginseng, thus enhancing the medicinal efficacy of ginseng products.

Keywords: Panax ginseng, Germanium, Absorption, Accumulation, Soil

\section{INTRODUCTION}

Germanium is a lustrous, hard, grayish-white metalloid element discovered in argyrodite by the German chemist Clemens Winkler in 1886. It has the symbol Ge, atomic number 32 , atomic mass number 72.64 , melting point $938.25^{\circ} \mathrm{C}$, boiling point $2,833^{\circ} \mathrm{C}$, and specific gravity of 5.35 ; it belongs to group $4 \mathrm{~A}$ in the periodic table, which also contains $\mathrm{C}, \mathrm{Si}, \mathrm{Sn}$, and $\mathrm{Pb}$. It is classified into inorganic and organic germanium, the latter when combined with organic matter (organometallic compound).

The curative properties of inorganic germanium have received attention since high amounts were detected in the 1930s in chemical analyses of spring water considered to be curative at Lourdes, located on the border area between Spain and France [1,2]. Inorganic germanium is mainly used in industrial semiconductor production as well as in, e.g., cosmetics, clothes, and furniture.

The average soil content of inorganic germanium in Gyeongnam province, Korea, is $0.24 \mathrm{mg} / \mathrm{kg}$ in paddy field soils, reaching $0.30 \mathrm{mg} / \mathrm{kg}$ in Masan, Jinju, and Hadonggun. The content varies depending on soil type: $0.27 \mathrm{mg} / \mathrm{kg}$ in common rice paddy and silty loam rice paddy soils, which is more than in sandy and wetted paddy soils [3].

The germanium content of ashed crop plants was found to be $20 \mathrm{mg} / \mathrm{kg}$ [4], ranging from 0.1 to $1.0 \mathrm{mg} / \mathrm{kg}$, although medicinal plants contain higher amounts. Yang and Zhang [5] reported a germanium content of $82 \mu \mathrm{g} / \mathrm{kg}$

\footnotetext{
(c) This is an Open Access article distributed under the terms of the Creative Commons Attribution Non-Commercial License (http://creativecommons.org/licenses/by-nc/3.0/) which permits unrestricted non-commercial use, distribution, and reproduction in any medium, provided the original work is properly cited.
}

Received 14 May. 2010, Revised 13 Jul. 2010, Accepted 14 Jul. 2010

*Corresponding author

E-mail: jykang@kgc.or.kr

Tel: +82-42-870-3111, Fax: +82-42-870-3117 
in ginseng, $88 \mu \mathrm{g} / \mathrm{kg}$ in fungi, $75 \mu \mathrm{g} / \mathrm{kg}$ in chrysanthemum, and $88 \mu \mathrm{g} / \mathrm{kg}$ in ginkgo leaf. The germanium content in Angelica keiskei growing in Korea differs by 3.8fold in leaves and 5.0-fold in stems depending on the cultivation region, and leaves contain 13.3 times more germanium than stems, i.e., $386 \mathrm{mg} / \mathrm{kg}$ and $29 \mathrm{mg} / \mathrm{kg}$, respectively [6].

Inorganic germanium occurs naturally in soils and is absorbed by and accumulates in animals, plants, and microorganisms, in which it is transformed into organic germanium compounds having increased physiological compatibility. Relatively large amounts of natural organic germanium compounds are found in medicinal plants with recuperative and tonic effects such as ginseng, Ganoderma, Angelica keiskei, and garlic [7,8].

Recently, several studies have examined the organic germanium content in rice [9], lettuce [10], soybean sprouts [11], Chinese cabbage [12], and ginseng [13]. However, the absorption and accumulation of inorganic soil germanium by ginseng plants had not yet been fully characterized. Thus, this study examined ginseng plants grown in soil supplemented with inorganic germanium to assess its absorption by the ginseng, accumulation in different plant parts, effects on chemical components of the soil, and content of ginsenosides. The findings of this study will provide useful information on the application of germanium to ginseng as a new bioactive substance.

\section{MATERIALS AND METHODS}

\section{Germanium treatment}

The experiment for examining the absorption and accumulation of soil germanium by ginseng was conducted in an experimental ginseng field of the KT\&G Central Research Institute in Suwon, Korea. Four-year-old ginseng plants (violet-stem native variant, Jakyungjong) were planted in fields supplemented with inorganic ger- manium metallic compounds containing germanium dioxide and germanium chloride under shading with four layers (one black and three blue) of polyethylene net. The completely randomized experimental design comprised nine ginseng fields, each composed of three plots (kans) (replications) of about $1.6 \mathrm{~m}^{2}$. The metallic germanium compounds were applied in different amounts (20 g, $40 \mathrm{~g}$, and $80 \mathrm{~g} / \mathrm{plot}$ applied to all experimental plots in June) at different times (one to three times), with a non-application control. The compounds were applied to all experimental plots on 14 June 2008, with second or third applications to selected plots on 23 July 2008 and 7 August 2008, respectively.

\section{Soil sampling}

Soil samples of $200 \mathrm{~g}$ to $300 \mathrm{~g}$ were taken from $5 \mathrm{~cm}$ to $20 \mathrm{~cm}$ below the surface in five areas of each experimental plot in a zigzag pattern. Debris was removed and soil samples were air-dried under shade for 2 weeks. The dried soil samples were sieved through a 10-mesh sieve prior to use in the experiments.

\section{Analysis of soil germanium}

To analyze the soil germanium content, $10 \mathrm{~mL}$ of ultrapure grade- $\mathrm{HNO}_{3}$ was added to $0.5 \mathrm{~g}$ soil samples and digested in a MARS Microwave Digestion System (CEM Corporation, Matthews, NC, USA) under the conditions shown in Table 1, and then cooled to room temperature. The digested soil solutions were diluted with deionized water to a total volume of $50 \mathrm{~mL}$ with a specific resistance over $18.2 \mathrm{M} \Omega / \mathrm{cm}$, and then subjected to analysis of germanium content using a 7500 ICP-MS (Agilent, Vernon Hills, IL, USA) (Table 1).

\section{Analyses of the physicochemical characteristics of soil}

The experimental field soils supplemented with inorganic

Table 1. Microwave digestion parameters for dissolving the germanium in plant and soil

\begin{tabular}{cccccc}
\hline Step & Type & Temperature $\left({ }^{\circ} \mathrm{C}\right)$ & Power $(\%)$ & Ramp $(\mathrm{min})$ & Dwell ${ }^{\text {1) }}(\mathrm{min})$ \\
\hline 1 & & \multicolumn{2}{c}{ First digestion program } & 10 & 10 \\
2 & Time to temp & 140 & 60 & 60 & - \\
3 & Time to temp & 160 & - & & 30 \\
\hline 1 & Cooling & \multicolumn{2}{c}{ Second digestion program } & 10 & 10 \\
2 & Time to temp & 140 & 60 & 10 & 20 \\
3 & Time to temp & 180 & 60 & - & 30 \\
\hline
\end{tabular}

\footnotetext{
${ }^{11}$ Regular halt along the step changing.
} 
germanium were analyzed for $\mathrm{pH}$, electric conductivity (EC), available phosphate, and exchangeable cations (K, $\mathrm{Ca}$, and $\mathrm{Mg}$ ) according to the methods described in National Institute of Agricultural Science and Technology (Korea) [14]. Soil pH and EC were measured using 5-g soil samples suspended in $25 \mathrm{~mL}$ of distilled water, after a $1 \mathrm{~h}$ agitation, with a D-12 pH meter (Horiba, Fukuoka, Japan) and a DS- 15 conductivity meter (Horiba). The amount of available phosphates (average $\mathrm{P}_{2} \mathrm{O}_{5}$ ) was determined by the Lancaster method using $5 \mathrm{~g}$ of soil in a $125-\mathrm{mL}$ flask with $20 \mathrm{~mL}$ of extraction solution, followed by 10 min agitation and passage through filter paper (No. 2; Toyo Roshi, Tokyo, Japan); the solution was then transferred to a test tube with $3 \mathrm{~mL}$ of the standard solution, 3 $\mathrm{mL}$ of the sample solution, and $6 \mathrm{~mL}$ of the manipulated solution with an additional supplementation of $0.4 \mathrm{~mL}$ 1-amino-2-naphthol-4-sulfonic acid. The pretreated samples were incubated at $30^{\circ} \mathrm{C}$ for $30 \mathrm{~min}$ and analyzed with a Varian Cary IE UV/Visible spectrophotometer (Spectra Lab Scientific, Toronto, ON, Canada) at an absorption wavelength of $720 \mathrm{~nm}$. Soluble cations $\left(\mathrm{K}^{+}\right.$, $\mathrm{Ca}^{2+}$, and $\mathrm{Mg}^{2+}$ ) were determined by photometry with a Varian Cary IE UV/Visible Spectrophotometer (Spectra Lab Scientific) using 5-g soil samples. Soluble cations $\left(\mathrm{Ca}^{2+}, \mathrm{Na}^{+}, \mathrm{K}^{+}\right.$, and $\left.\mathrm{Mg}^{2+}\right)$ were determined using a flame photometer and $5 \mathrm{~g}$ of soil dissolved in extraction solu-

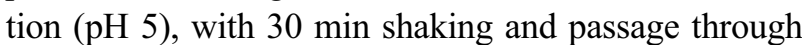
filter paper (No. 2, Toyo Roshi), and were measured in an Optima 5300DV inductively coupled plasma-optical emission spectrometer (ICP-OES; Perkin-Elmer Inc., University Park, PA, USA).

\section{Ginseng sampling}

Aboveground plant parts of 4-year-old ginseng plants grown in field soils supplemented with inorganic germanium compounds were harvested by cutting at the stem base on 28 September 2008, rinsed twice in distilled water, and dried at $80^{\circ} \mathrm{C}$ for $10 \mathrm{~h}$ in a hot-air circula- tion dryer (Eyela, Bohemia, NY, USA). The dried plant material was ground to a powder in a rotary mill and sieved through a 40-mesh sieve; it was then only used for chemical analyses. For analysis of belowground plant parts, 4-year-old ginseng roots (including rhizomes) were carefully pulled out without damaging the fine roots using a ginseng-digging hoe on 29 September 2008 , washed with distilled water, and dried at $60^{\circ} \mathrm{C}$ for 3 days in a hot-air circulation dryer (Eyela). The dried ginseng roots (main roots and lateral roots) and rhizomes were separated and ground to a powder in a rotary mill, sieved through a 40-mesh sieve, and then used for chemical analyses.

\section{Analysis of germanium content in ginseng}

To analyze the germanium content, 0.5 -g plant samples were added to $10 \mathrm{~mL}$ of ultrapure grade $\mathrm{HNO}_{3}$ and digested in a MARS Microwave Digestion System (CEM Corporation) as described in Table 1 and then cooled to room temperature. The digested soil solutions were diluted with deionized water to a total volume of $50 \mathrm{~mL}$ with a specific resistance over $18.2 \mathrm{M} \Omega / \mathrm{cm}$ and subjected to analysis of germanium content using an Agilent 7500 ICP-MS (Table 2).

\section{Analysis of ginsenosides in ginseng}

To analyze ginsenosides, 1-g plant samples were dissolved in $50 \%$ aqueous methanol in a $250-\mathrm{mL}$ reflux flask, with reflux extraction at $75^{\circ} \mathrm{C}$ for $1 \mathrm{~h}$ in a water bath; the solution was then cooled to room temperature and centrifuged, after which the supernatant was collected. The supernatant was combined with the first extracted supernatant and condensed in reduced pressure at $60^{\circ} \mathrm{C}$ in a rotary vacuum evaporator. The condensed samples were dissolved in $2 \mathrm{~mL}$ of water/acetonitrile $(80: 20, \mathrm{v} / \mathrm{v})$ and filtered through a $0.45-\mu \mathrm{m}$ membrane filter. The samples were then analyzed by HPLC (Alliance 2695; Waters Corporation, Milford, MA, USA) on

Table 2. Optimum instrumental conditions for ICP-MS ${ }^{1)}$ operation for the germanium analysis

\begin{tabular}{ll}
\multicolumn{1}{c}{ Parameters } & \multicolumn{1}{c}{ Conditions } \\
\hline Plasma parameters & $1,500 \mathrm{~W}$ \\
Rf power & $15 \mathrm{~L} / \mathrm{min}$ \\
Plasma gas flow rate & $1 \mathrm{~L} / \mathrm{min}$ \\
Auxiliary gas flow rate & $1 \mathrm{~L} / \mathrm{min}$ \\
Carrier gas flow rate & $\mathrm{Nickel}, 1$ and $0.4 \mathrm{~mm} \mathrm{id}$ \\
Sampler and skimmer & Optimised for best sensitivity of $10 \mathrm{~g} / \mathrm{Li}, \mathrm{Co}, \mathrm{Y}$ and TI $1 \%(\mathrm{v} / \mathrm{v}) \mathrm{HNO} 3$ solution \\
Ion lens setting & 3 \\
Data acquisition parameters & $0.3 \mathrm{sec}$ \\
Points per peak & 3 \\
Integration time per point & \\
Replicates &
\end{tabular}

${ }^{1)}$ Inductively coupled plasma-mass spectrometer, Agilent $7500 \mathrm{C}$. 
Table 3. The composition of mobile phase in HPLC for the ginsenoside analysis

\begin{tabular}{ccc}
\hline \multirow{2}{*}{ Time (min) } & \multicolumn{2}{c}{ Mobile phase $^{1)}$} \\
\cline { 2 - 3 } & Solvent A (\%) & Solvent B (\%) \\
\hline 0 & 20 & 80 \\
10 & 20 & 80 \\
40 & 32 & 68 \\
48 & 42 & 58 \\
50 & 100 & 0 \\
60 & 100 & 0 \\
62 & 20 & 80 \\
70 & 20 & 80 \\
\hline
\end{tabular}

${ }^{1)}$ Solvent A, 100\% acetonitrile; Solvent B, 100\% distilled water.

a $250 \times 4.6-\mathrm{mm}$ Hyersil ODS $5-\mu \mathrm{m}$ column in a mixture of acetonitrile and distilled water (Table 3 ) and flow velocity of $1.6 \mathrm{~mL} / \mathrm{min}$, then measured at $203 \mathrm{~nm} \mathrm{UV} \mathrm{[15].}$

\section{RESULTS AND DISCUSSION}

\section{Germanium content in soil}

In fields containing 4-year-old ginseng plants, the germanium content in soil with no added germanium was $0.20 \mathrm{mg} / \mathrm{kg}$, which was close to the average germanium content in paddy field soil in Geongnam province [9]. The germanium content in soil treated with inorganic germanium compounds was $4.05,4.46$, or $4.52 \mathrm{mg} / \mathrm{kg}$ after one, two, or three applications of $20 \mathrm{~g} / \mathrm{plot}$, respectively; $4.98,5.98$, or $7.09 \mathrm{mg} / \mathrm{kg}$ after one, two, or three applications of $40 \mathrm{~g} /$ plot, respectively; and 6.73, 7.99, or $8.65 \mathrm{mg} / \mathrm{kg}$ after one, two, or three applications of 80 $\mathrm{g} / \mathrm{plot}$, respectively. These results suggest that the germanium content in soil increased significantly $(p \leq 0.05)$ with increases in the amount and frequency of application. The germanium content in soil was divided into five groups (levels) according to analysis with Duncan's multiple range test (DMRT) at $p \leq 0.05$ : group 1 was the nontreatment control, group II had one to three applications of $20 \mathrm{~g} / \mathrm{plot}$ and one application of $40 \mathrm{~g} / \mathrm{plot}$, group III had two applications of $40 \mathrm{~g} /$ plot, group IV had three applications of $40 \mathrm{~g} / \mathrm{plot}$ and one with $80 \mathrm{~g} / \mathrm{plot}$, and group $\mathrm{V}$ had two or three applications of $80 \mathrm{~g} /$ plot (Table 4).

The germanium content of the inorganic germanium metallic compounds was $48.88 \mathrm{~g} / \mathrm{kg}$; therefore, $20 \mathrm{~g}$, 40 $\mathrm{g}$, and $80 \mathrm{~g}$ of germanium compounds applied in each plot contained $0.98,1.96$, and $3.92 \mathrm{~g}$ of inorganic germanium, respectively. The content of germanium in a plot ([plot area, $180 \mathrm{~cm} \times 90 \mathrm{~cm}] \times[$ effective plot depth, 10 $\mathrm{cm}] \times\left[\right.$ soil density, $\left.1.2 \mathrm{~g} / \mathrm{cm}^{3}\right]=194.4 \mathrm{~kg}$ ) was theoretically $5.03,10.01$, and $20.11 \mathrm{mg} / \mathrm{kg}$ for the three treatments, respectively. These values are far greater than the actual germanium content examined in the plots, probably because the amount of germanium metallic compounds had decreased beyond the top soil layer of $0 \mathrm{~cm}$ to $5 \mathrm{~cm}$ depth. However, the germanium content in soil increased with the increase in application frequency, except in the $20 \mathrm{~g} /$ plot treatment, suggesting that artificial fertilization with germanium metallic compounds increases the germanium content in soil.

\section{Changes in physicochemical soil characteristics}

The physicochemical changes ( $\mathrm{pH}, \mathrm{EC}$, average phosphates, soluble cations of $\mathrm{K}, \mathrm{Ca}$, and $\mathrm{Mg}$ ) of the experimental field soils supplemented with different amounts of germanium metallic compounds at different frequencies are shown in Tables 5 and 6 . The $\mathrm{pH}$ was 4.63 to 4.96 in the soil with germanium treatment, which is not significantly different from $\mathrm{pH} 4.87$ in soils of the nontreatment control, suggesting that the ginseng growth may not

Table 4. Changes of chemical properties in soil treated with inorganic germanium (Ge)

\begin{tabular}{|c|c|c|c|c|c|c|c|}
\hline \multirow{2}{*}{$\begin{array}{c}\text { Inorganic Ge } \\
\text { amounts } \\
\left(\mathrm{g} / \mathrm{plot}^{1)}\right)\end{array}$} & \multirow{2}{*}{$\begin{array}{c}\text { Ge input } \\
\text { times }\end{array}$} & \multirow{2}{*}{$\mathrm{pH}$} & \multirow{2}{*}{$\begin{array}{c}\mathrm{EC} \\
(\mathrm{dS} / \mathrm{m})\end{array}$} & \multirow{2}{*}{$\begin{array}{l}\mathrm{Av}_{2} \mathrm{O}_{5} \\
(\mathrm{mg} / \mathrm{kg})\end{array}$} & \multicolumn{3}{|c|}{ Ex cation $(\mathrm{cmol} / \mathrm{kg})$} \\
\hline & & & & & $\mathrm{Ca}$ & K & $\mathrm{Mg}$ \\
\hline \multirow[t]{2}{*}{0} & - & 4.87 & 0.84 & 71.81 & 3.87 & 1.03 & 1.81 \\
\hline & 1 & 4.63 & 0.83 & 52.94 & 3.38 & 0.72 & 1.48 \\
\hline \multirow[t]{3}{*}{20} & 2 & 4.79 & 0.62 & 65.31 & 3.55 & 0.89 & 1.42 \\
\hline & 3 & 4.81 & 1.09 & 67.42 & 3.87 & 0.99 & 1.67 \\
\hline & 1 & 4.73 & 0.64 & 63.57 & 3.43 & 0.85 & 1.48 \\
\hline \multirow[t]{3}{*}{40} & 2 & 4.79 & 0.66 & 60.18 & 3.31 & 0.97 & 1.41 \\
\hline & 3 & 4.96 & 0.51 & 67.14 & 4.03 & 0.94 & 1.72 \\
\hline & 1 & 4.69 & 0.87 & 60.18 & 3.94 & 0.89 & 1.97 \\
\hline \multirow[t]{2}{*}{80} & 2 & 4.91 & 0.41 & 61.46 & 3.40 & 0.86 & 1.56 \\
\hline & 3 & 4.92 & 0.59 & 59.36 & 3.79 & 0.94 & 1.63 \\
\hline
\end{tabular}

$\mathrm{EC}$, electric conductivity; $\mathrm{Av}$, available; Ex, exchangeable.

${ }^{1)}$ Plantation unit area (kan) $(180 \mathrm{~cm} \times 90 \mathrm{~cm})$ of Panax ginseng C. A. Meyer. 
Table 5. Correlation coefficients for germanium $(\mathrm{Ge})$ content with physico-chemical properties in soil treated with inorganic Ge

\begin{tabular}{ccccccc}
\hline $\mathrm{Ge}$ & $\mathrm{pH}$ & $\mathrm{EC}$ & $\mathrm{Av} \mathrm{P}_{2} \mathrm{O}_{5}$ & $\mathrm{Ca}$ & $\mathrm{K}$ & $\mathrm{Mg}$ \\
\hline $\mathrm{Ge}$ & 0.293 & -0.544 & -0.456 & -0.026 & -0.191 & -0.051 \\
$\mathrm{pH}$ & & -0.509 & 0.533 & 0.390 & 0.602 & 0.138 \\
$\mathrm{EC}$ & & & 0.118 & 0.309 & 0.179 & 0.359 \\
$\mathrm{Av} \mathrm{P}_{2} \mathrm{O}_{5}$ & & & & 0.534 & $0.770^{* *}$ & 0.327 \\
$\mathrm{Ca}$ & & & & 0.529 & $0.836^{* *}$ \\
$\mathrm{~K}$ & & & & & & 0.365 \\
\hline
\end{tabular}

be adversely affected by $\mathrm{pH}$ changes due to the germanium treatment. However, the $\mathrm{pH}$ was slightly lower than the $\mathrm{pH} 5.0$ to 6.0 optimum for ginseng growth. The EC of soil treated with germanium metallic compounds was 0.41 to $1.09 \mathrm{dS} / \mathrm{m}$, a wider range than that of the nontreatment control $(0.84 \mathrm{dS} / \mathrm{m})$; however, ginseng growth is unlikely to be adversely affected, as the EC value of ginseng field soils allowable for ginseng cultivation is 0.5 to $1.0 \mathrm{dS} / \mathrm{m}$. A correlation appeared to exist between increased germanium and decreased EC, but it was not significant. Also, the salt toxicity of soils with a high EC may be reduced by inorganic germanium amendment, leading to improved growth of ginseng plants, which are vulnerable to high soil salt content.

The available phosphate (average $\mathrm{P}_{2} \mathrm{O}_{5}$ ) in plots without germanium treatment was $71.81 \mathrm{mg} / \mathrm{kg}$, which is lower than in most ginseng fields in Korea, probably because the experimental ginseng field is on reclaimed land in the mountainous area. However, the average $\mathrm{P}_{2} \mathrm{O}_{5}$ content tended to decrease proportionally to 52.94 to $67.42 \mathrm{mg} / \mathrm{kg}$ with increasing amounts of germanium, although this change was not significant at $p \leq 0.05$. Further studies on the effect of germanium treatment on the average $\mathrm{P}_{2} \mathrm{O}_{5}$ content of soil are needed as phosphates are immobilized in soils with low $\mathrm{pH}$ and ginseng growth is adversely influenced by high phosphate content derived from overuse of chemical and livestock manure fertilizers.

For exchangeable cations, $\mathrm{Ca}^{2+}$ content was 3.31 to 4.03 $\mathrm{cmol}^{+} / \mathrm{kg}$ after germanium treatment and $3.87 \mathrm{cmol}^{+} /$ $\mathrm{kg}$ in the non-treated control plots, tending to increase with increased germanium, but without significance. These values were in the range of $\mathrm{Ca}^{2+}$ content of 2.0 to $4.5 \mathrm{cmol}^{+} / \mathrm{kg}$ for optimum ginseng growth. The content of exchangeable $\mathrm{K}^{+}$was $1.03 \mathrm{cmol}^{+} / \mathrm{kg}$ in the nontreated control, which is above the allowable content of $0.8 \mathrm{cmol}^{+} / \mathrm{kg}$ for ginseng growth; however, the value decreased to 0.72 to $0.97 \mathrm{cmol}^{+} / \mathrm{kg}$ after germanium treatment and tended to decrease proportionally with in- creases in the amount of germanium, but without significance at $p \leq 0.05$. The correlation coefficient for $\mathrm{K}^{+}$with average $\mathrm{P}_{2} \mathrm{O}_{5}$ was 0.770 , indicating a highly significant correlation $(p \leq 0.01)$. The content of exchangeable $\mathrm{Mg}^{2+}$ was $1.81 \mathrm{cmol}^{+} / \mathrm{kg}$ in the non-treated control and 1.41 to $1.91 \mathrm{cmol}^{+} / \mathrm{kg}$ in germanium treatments, but was not significant at $p=0.05$, and was within the range of $\mathrm{Mg}^{2+}$ allowable for ginseng growth. The correlation coefficient for $\mathrm{Mg}^{2+}$ and $\mathrm{Ca}^{2+}$ was 0.836 , indicating a highly significant $(p=0.01)$ correlation.

All of the results in our study suggest that the content of chemical components of soil generally decreased with increasing germanium treatment. However, another study on the production of watermelon after germanium treatment [16] showed that application of 1,2 , and 3 tons/ha of biotite containing $38.5 \mathrm{mg} / \mathrm{kg}$ germanium increased the $\mathrm{pH}$, organic matter, available phosphates, total nitrogen, and $\mathrm{NO}_{3}-\mathrm{N}$, but decreased the exchangeable cations $\mathrm{K}^{+}, \mathrm{Ca}^{2+}, \mathrm{Mg}^{2+}$, and EC. Thus, the correlations between chemical characteristics of the soil and germanium treatment require further study.

\section{Germanium content in ginseng}

Responses of 4-year-old ginseng plants to different amounts and frequencies of germanium treatment were examined in relation to plant absorption or exclusion of inorganic germanium. The germanium content in ginseng stems was $2.29 \mathrm{mg} / \mathrm{kg}$, about 9.5 times higher than in the control $(0.24 \mathrm{mg} / \mathrm{kg})$, and increased significantly $(p \leq 0.05)$ with increasing amount and frequency of treatment. The germanium content in soil could be divided into six groups (levels) according to DMRT at $p \leq 0.05$ : group 1 was the nontreatment control, group II had one or two applications of $20 \mathrm{~g} / \mathrm{plot}$, group III had three application with $20 \mathrm{~g} / \mathrm{plot}$ and one or two applications with $40 \mathrm{~g} / \mathrm{plot}$, group IV had three applications of $40 \mathrm{~g} / \mathrm{plot}$, group V had one application of $80 \mathrm{~g} / \mathrm{plot}$, and group VI had one or two applications of $80 \mathrm{~g} / \mathrm{plot}$ (Table 6).

The germanium content in ginseng leaves was 2.20 
Table 6. Comparison of germanium contents in the 4-year-old Panax ginseng grown in fields treated with inorganic germanium (Ge) (mg/kg)

\begin{tabular}{|c|c|c|c|c|c|c|}
\hline \multirow{2}{*}{$\begin{array}{l}\text { Inorganic Ge amounts } \\
\qquad\left(\mathrm{g} / \mathrm{kan}^{1 /}\right)\end{array}$} & \multirow{2}{*}{ Ge input times } & \multicolumn{2}{|c|}{ Germanium contents of aerial parts } & \multicolumn{3}{|c|}{ Germanium contents of under parts } \\
\hline & & Stem & Leaf & Rhizome & Main root & Lateral root \\
\hline \multirow[t]{2}{*}{0} & - & $0.24 \pm 0.02^{\mathrm{a} 2)}$ & $0.31 \pm 0.01^{\mathrm{a}}$ & $0.20 \pm 0.01^{\mathrm{a}}$ & $0.09 \pm 0.01^{\mathrm{a}}$ & $0.12 \pm 0.01^{\mathrm{a}}$ \\
\hline & 1 & $1.43 \pm 0.09^{\mathrm{b}}$ & $0.56 \pm 0.01^{\mathrm{a}}$ & $1.21 \pm 0.14^{\mathrm{b}}$ & $0.13 \pm 0.01^{\mathrm{b}}$ & $0.22 \pm 0.02^{\mathrm{b}}$ \\
\hline \multirow[t]{3}{*}{20} & 2 & $1.44 \pm 0.05^{\mathrm{b}}$ & $0.54 \pm 0.47^{\mathrm{a}}$ & $2.32 \pm 0.09^{\mathrm{d}}$ & $0.31 \pm 0.02^{\mathrm{b}}$ & $0.25 \pm 0.02^{\mathrm{bc}}$ \\
\hline & 3 & $1.75 \pm 0.09^{\mathrm{c}}$ & $1.14 \pm 0.06^{\mathrm{b}}$ & $2.06 \pm 0.06^{\mathrm{c}}$ & $0.21 \pm 0.01^{\mathrm{cd}}$ & $0.29 \pm 0.01^{\mathrm{c}}$ \\
\hline & 1 & $1.79 \pm 0.10^{\mathrm{c}}$ & $1.28 \pm 0.03^{\mathrm{b}}$ & $2.42 \pm 0.07^{\mathrm{d}}$ & $0.20 \pm 0.01^{\mathrm{c}}$ & $0.26 \pm 0.02^{\mathrm{cd}}$ \\
\hline \multirow[t]{3}{*}{40} & 2 & $1.80 \pm 0.14^{\mathrm{c}}$ & $1.38 \pm 0.12^{\mathrm{b}}$ & $3.07 \pm 0.16^{\mathrm{e}}$ & $0.21 \pm 0.01^{\mathrm{cd}}$ & $0.34 \pm 0.02^{\mathrm{d}}$ \\
\hline & 3 & $2.07 \pm 0.07^{\mathrm{d}}$ & $2.63 \pm 0.10^{\mathrm{d}}$ & $3.63 \pm 0.10^{\mathrm{f}}$ & $0.23 \pm 0.02^{\mathrm{d}}$ & $0.40 \pm 0.01^{\mathrm{e}}$ \\
\hline & 1 & $2.45 \pm 0.15^{\mathrm{e}}$ & $1.97 \pm 0.19^{\mathrm{c}}$ & $3.87 \pm 0.15^{\mathrm{g}}$ & $0.30 \pm 0.02^{\mathrm{e}}$ & $0.47 \pm 0.02^{\mathrm{f}}$ \\
\hline \multirow[t]{2}{*}{80} & 2 & $3.55 \pm 0.06^{\mathrm{f}}$ & $4.17 \pm 0.23^{\mathrm{e}}$ & $4.27 \pm 0.13^{\mathrm{h}}$ & $0.39 \pm 0.01^{\mathrm{f}}$ & $0.68 \pm 0.01^{\mathrm{g}}$ \\
\hline & 3 & $4.34 \pm 0.10^{\mathrm{g}}$ & $6.11 \pm 0.18^{\mathrm{f}}$ & $5.34 \pm 0.26^{\mathrm{i}}$ & $0.53 \pm 0.03^{\mathrm{g}}$ & $0.88 \pm 0.05^{\mathrm{h}}$ \\
\hline
\end{tabular}

Numeric values are mean \pm standard error.

1) Plantation unit area $(180 \mathrm{~cm} \times 90 \mathrm{~cm})$ of Panax ginseng C. A. Meyer.

${ }^{2)}$ Means in a column with superscripts without a common letter differ, $p<0.05$.

$\mathrm{mg} / \mathrm{kg}$ in the germanium treatments, about 7.1 times higher than in the control $(0.31 \mathrm{mg} / \mathrm{kg})$. The germanium content in stems increased significantly $(p \leq 0.05)$ with increasing amount and frequency of treatment. The germanium content could be divided into six groups (levels) according to DMRT at $p \leq 0.05$ : group 1 was the control with one or two applications of $20 \mathrm{~g} / \mathrm{plot}$, group II had three applications of $20 \mathrm{~g} / \mathrm{plot}$ and one or two of $40 \mathrm{~g} /$ plot, group III had one application of $80 \mathrm{~g} / \mathrm{plot}$, group IV had three applications of $40 \mathrm{~g} / \mathrm{plot}$, group $\mathrm{V}$ had two applications of $80 \mathrm{~g} / \mathrm{plot}$, and group VI had three applications of $80 \mathrm{~g} / \mathrm{plot}$ (Table 6).

The germanium content in the ginseng rhizomes was $3.13 \mathrm{mg} / \mathrm{kg}$ in the germanium treatments, about 15.7 times higher than in the control $(0.20 \mathrm{mg} / \mathrm{kg})$, and it increased significantly $(p \leq 0.05)$ with increasing amount and frequency of the treatment. The results could be divided into 10 groups according to DMRT at $p \leq 0.05$ : group 1 was the control, group II had one application of $20 \mathrm{~g} /$ plot, group III had three applications of $20 \mathrm{~g} /$ plot, group IV had two applications of $20 \mathrm{~g} / \mathrm{plot}$, and groups $\mathrm{V}-\mathrm{X}$ had one to three applications of 40 and $80 \mathrm{~g} /$ plot (Table 6 and Fig. 1).

The germanium content in the main root of ginseng was less than in the stem and leaf: $0.09 \mathrm{mg} / \mathrm{kg}$ in the control, increasing 2.9-fold to $0.26 \mathrm{mg} / \mathrm{kg}$ after the germanium treatment. The germanium content in the main root also increased significantly $(p \leq 0.05)$ with increasing amount and frequency of germanium treatment, which could be divided into six groups according to DMRT at $p \leq 0.05$ : group I was the control, group II had one and two applications of $20 \mathrm{~g} /$ plot, group III had three applications of $20 \mathrm{~g} /$ plot and one or two applications of $40 \mathrm{~g} /$ plot, and groups IV-VI had one to three applications of

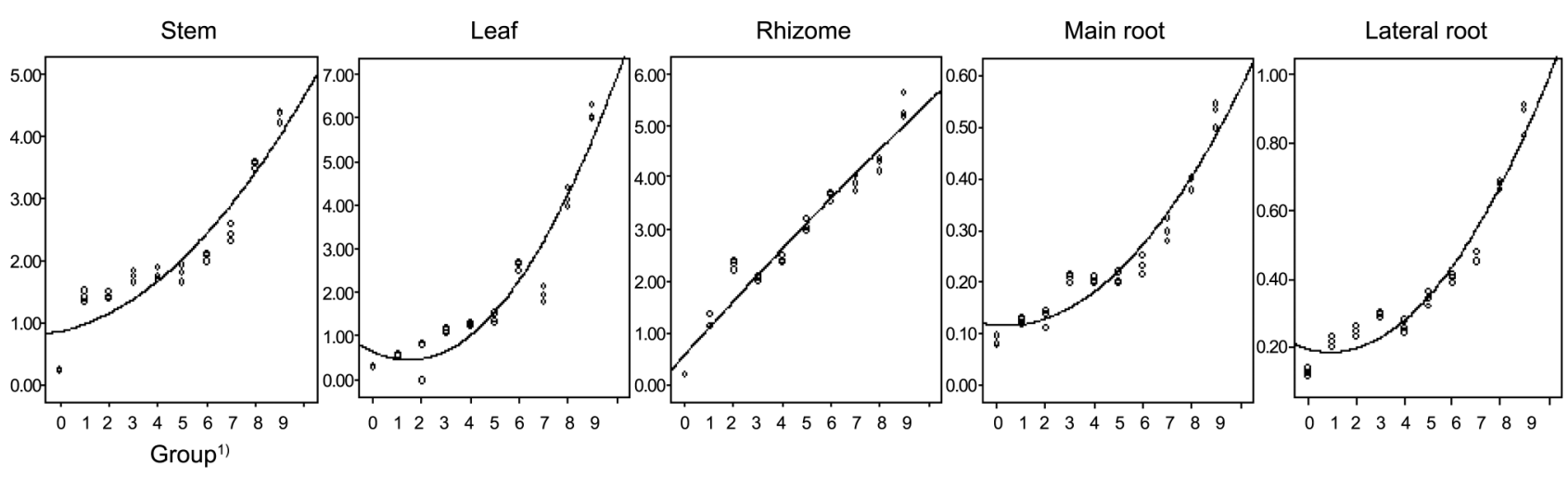

Fig. 1. Regression curves of germanium (Ge) content in 4-year-old Panax ginseng grown in fields treated with Ge. ${ }^{11}$ Treatments: 0 , control; $1-3$, inorganic Ge 20 g/plot, 1-3 input times; 4-6, inorganic Ge 40 g/plot, 1-3 input times; 7-9, inorganic Ge 80 g/plot, 1-3 input times (plot: plantation

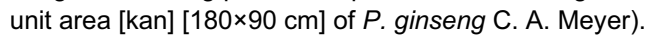


$80 \mathrm{~g} /$ plot (Table 6).

The germanium content in lateral roots was $0.42 \mathrm{mg} /$ $\mathrm{kg}$ after treatment, which was 3.5 times higher than in the control $(0.12 \mathrm{mg} / \mathrm{kg})$. As in other parts of the ginseng plant, especially the main root, the germanium content in lateral roots increased significantly $(p \leq 0.05)$ with increasing amount and frequency of germanium treatments. From DMRT at $p \leq 0.05$, the germanium content in lateral roots could be divided into six groups: group I was the control, group II had one to three applications of $20 \mathrm{~g} / \mathrm{plot}$ and one or two applications of $40 \mathrm{~g} / \mathrm{plot}$, group III had three applications of $40 \mathrm{~g} / \mathrm{plot}$, and groups IV-VI had one to three applications of $80 \mathrm{~g} / \mathrm{kg}$ (Table 6).

\section{Survival strategy of ginseng for inorganic germa- nium}

The germanium content in ginseng increased significantly with increasing germanium content in soil, from a minimum of 2.9 times to a maximum 9.5 times, depending on the plant part, in the order of rhizome, stem, leaf, lateral root, and main root. The maximum germanium content was $6.11 \mathrm{mg} / \mathrm{kg}$ in the leaf. Regression analysis in relation to the germanium content of soil gave high coefficients of determination $\left(\mathrm{R}^{2}\right)$ of 0.914 for the leaf, 0.884 for the stem, 0.950 for the rhizome, 0.931 for the main root, and 0.945 for the lateral root (Fig. 1).

Among medicinal plants, the germanium content is reportedly over $100 \mu \mathrm{g} / \mathrm{kg}$ in Artemisia capillaris, Angelica polymorpha, ginseng, Atractylodes japonica, Angelica dahurica, Liriope platyphylla, and Platycodon grandiflorum [3]. The germanium content is $22 \mu \mathrm{g} / \mathrm{kg}$ in ginseng, $539 \mu \mathrm{g} / \mathrm{kg}$ in rice, $29 \mu \mathrm{g} / \mathrm{kg}$ in soybean leaves, and $49 \mu \mathrm{g} / \mathrm{kg}$ in perilla leaves in Guemsan, Chungnam province, Korea, while it is $3 \mu \mathrm{g} / \mathrm{kg}$ in ginseng, $1 \mu \mathrm{g} / \mathrm{kg}$ in rice, and $19 \mu \mathrm{g} / \mathrm{kg}$ in chili pepper [17]. Considering the germanium content of ginseng $(22 \mu \mathrm{g} / \mathrm{kg})$ and the report of Yang and Zhang [5] stating that the germanium content in ginseng was $82 \mu \mathrm{g} / \mathrm{kg}$, the germanium content in ginseng in our study was very high.

Many plants can survive in areas with a high content of heavy metals such as nickel, chromium, cadmium, and arsenic either through exclusion or absorption of such metals. For the exclusion of heavy metals, absorption is prevented through differential permeability of the plasma membrane of root cells. Other plants, however, absorb and accumulate large amounts of heavy metals in cells, which can be fatal. Some accumulator species have real tolerance against heavy metal toxicity. Germanium was reported to accumulate in cells mainly as water-soluble fractions bound with nucleic acids and proteins [18]. Germanium in DNA of eukaryotic cells is involved in the control of genetic expression at the electron level by maintaining the level and direction of freesliding electrons in DNA and modulating the electron conductivity and conductivity of DNA [19].

In our study, ginseng did not appear to exclude, but absorb and accumulate, germanium proportionally to its content in soil. Little germanium was accumulated in roots that translocate germanium via the rhizome to the shoot (stem and leaf), which had the highest germanium content. Ginseng shoots containing high amounts of germanium are lost at the end of the growing season, resulting in removal of the germanium from the main plant parts (roots), which are replaced by new shoots at the beginning of the growing season in the next year. This is a sophisticated strategy of ginseng for removing germanium that prevents continuous germanium accumulation yearly that could threaten its survival. Further detailed examination of the production and trafficking of proteins in relation to nonmetallic and metallic compounds such as germanium are necessary to understand the survival strategy and medicinal efficacy of ginseng. Also, ginseng that has been grown in fields with a high germanium content may be utilized strategically for the production of specialized ginseng products.

\section{Changes in the ginsenoside content in ginseng}

The content of ginsenosides was examined in the rhizome, main root, and lateral root of 4-year-old ginseng treated with inorganic germanium compounds and showed a correlation between germanium content in ginseng and that in the soil (Table 7). The total ginsenoside content in the rhizome was $15.23 \mathrm{mg} / \mathrm{g}$ after germanium treatment, which was lower than in the control $(26.30 \mathrm{mg} / \mathrm{g})$. The correlation coefficients for ginsenoside content with soil germanium content were -0.710 for $R b_{1},-0.666$ for $\mathrm{Rb}_{2}$, -0.672 for $\mathrm{Re}$, and -0.669 for Rf, which were all negative at $p \leq 0.05$, suggesting that the content of ginsenosides in ginseng decreases with increased germanium in the soil. Ginsenoside content in the main root was 4.05 $\mathrm{mg} / \mathrm{g}$ after treatment, which is lower than in the control $(4.97 \mathrm{mg} / \mathrm{g})$, although the difference was not as high as in the rhizome. No significant correlations for ginsenoside content of the main root with that of the rhizome were noted; however, the main root ginsenoside content decreased with increasing soil germanium, showing significant negative correlations at $p \leq 0.05$ and correlation coefficients of -0.641 for $\mathrm{Rb}_{1},-0.691$ for $\mathrm{Rb}_{2},-0.642$ for Rc, -0.728 for Re, and -0.635 for Rf. Total ginsenosides in the lateral root were also lower in the germanium 
Table 7. Comparison of ginsenoside content in 4-year-old Panax ginseng grown in fields treated with inorganic germanium (Ge)

\begin{tabular}{|c|c|c|c|c|c|c|c|c|c|c|c|c|c|}
\hline \multirow{2}{*}{ Part } & \multirow{2}{*}{$\mathrm{Ge}^{1)}$} & \multicolumn{12}{|c|}{ Ginsenosides $(\mathrm{mg} / \mathrm{g}, \mathrm{w} / \mathrm{w})$} \\
\hline & & $\mathrm{Rb}_{1}$ & $\mathrm{Rb}_{2}$ & $\mathrm{Rc}$ & $\mathrm{Rd}$ & $\operatorname{Re}$ & $\mathrm{Rf}$ & $\mathrm{Rg}_{1}$ & $\mathrm{Rg}_{2}$ & $\mathrm{Rg}_{3}$ & $\mathrm{Rh}_{1}$ & Total & $\mathrm{PD} / \mathrm{PT}^{2)}$ \\
\hline \multirow{11}{*}{ Rhizome } & 0 & 7.94 & 2.87 & 3.37 & 2.00 & 4.39 & 1.71 & 2.25 & 1.09 & 0.51 & 0.17 & 26.30 & 1.74 \\
\hline & 1 & 4.60 & 2.19 & 2.60 & 1.38 & 2.70 & 0.93 & 1.43 & 0.68 & 0.34 & 0.11 & 16.96 & 1.90 \\
\hline & 2 & 4.36 & 1.81 & 2.17 & 1.15 & 2.57 & 0.63 & 1.23 & 0.67 & 0.33 & 0.10 & 15.02 & 1.88 \\
\hline & 3 & 4.07 & 1.73 & 2.05 & 0.96 & 2.34 & 0.70 & 1.24 & 0.63 & 0.31 & 0.11 & 14.14 & 1.82 \\
\hline & 4 & 3.89 & 1.60 & 1.95 & 1.05 & 2.11 & 0.68 & 1.28 & 0.60 & 0.28 & 0.10 & 13.54 & 1.83 \\
\hline & 5 & 3.79 & 1.67 & 2.03 & 0.79 & 2.17 & 0.67 & 1.18 & 0.63 & 0.30 & 0.10 & 13.33 & 1.81 \\
\hline & 6 & 3.88 & 1.82 & 2.18 & 1.02 & 2.31 & 0.72 & 1.40 & 0.67 & 0.31 & 0.12 & 14.43 & 1.76 \\
\hline & 7 & 5.21 & 2.16 & 2.53 & 1.35 & 2.92 & 0.95 & 1.86 & 0.86 & 0.39 & 0.15 & 18.38 & 1.73 \\
\hline & 8 & 4.70 & 1.80 & 2.32 & 1.33 & 2.60 & 0.96 & 1.54 & 0.76 & 0.35 & 0.12 & 16.48 & 1.75 \\
\hline & 9 & 3.88 & 1.85 & 2.29 & 1.11 & 2.52 & 0.64 & 1.34 & 0.70 & 0.34 & 0.11 & 14.78 & 1.78 \\
\hline & Cor & $-0.71^{\#}$ & $-0.67^{\#}$ & - & - & $-0.67^{\#}$ & $-0.67^{\#}$ & - & - & - & - & - & - \\
\hline \multirow{11}{*}{ Main root } & 0 & 1.29 & 0.57 & 0.69 & 0.13 & 0.72 & 0.42 & 0.95 & 0.08 & 0.12 & 0.00 & 4.97 & 1.28 \\
\hline & 1 & 1.21 & 0.60 & 0.72 & 0.17 & 0.57 & 0.44 & 1.07 & 0.00 & 0.11 & 0.08 & 4.97 & 1.31 \\
\hline & 2 & 0.81 & 0.35 & 0.45 & 0.11 & 0.45 & 0.25 & 0.63 & 0.00 & 0.10 & 0.00 & 3.15 & 1.36 \\
\hline & 3 & 1.15 & 0.46 & 0.61 & 0.13 & 0.60 & 0.35 & 0.75 & 0.00 & 0.11 & 0.00 & 4.16 & 1.44 \\
\hline & 4 & 1.48 & 0.56 & 0.72 & 0.16 & 0.58 & 0.47 & 1.20 & 0.10 & 0.13 & 0.10 & 5.50 & 1.25 \\
\hline & 5 & 1.15 & 0.50 & 0.65 & 0.12 & 0.58 & 0.39 & 0.88 & 0.00 & 0.11 & 0.00 & 4.38 & 1.37 \\
\hline & 6 & 0.96 & 0.46 & 0.59 & 0.15 & 0.55 & 0.32 & 0.77 & 0.00 & 0.10 & 0.00 & 3.90 & 1.37 \\
\hline & 7 & 1.27 & 0.56 & 0.69 & 0.17 & 0.62 & 0.39 & 0.99 & 0.09 & 0.12 & 0.07 & 4.97 & 1.31 \\
\hline & 8 & 0.72 & 0.27 & 0.38 & 0.09 & 0.37 & 0.28 & 0.65 & 0.00 & 0.09 & 0.00 & 2.85 & 1.19 \\
\hline & 9 & 0.60 & 0.27 & 0.40 & 0.08 & 0.35 & 0.20 & 0.53 & 0.00 & 0.09 & 0.00 & 2.52 & 1.33 \\
\hline & Cor & $-0.64^{*}$ & $-0.69^{*}$ & $-0.64^{*}$ & - & $-0.73^{*}$ & $\begin{array}{l}-0.64^{*} \\
-0.74^{\#}\end{array}$ & - & - & - & - & - & - \\
\hline \multirow{11}{*}{ Lateral root } & 0 & 5.02 & 3.05 & 3.81 & 1.43 & 3.60 & 0.89 & 1.27 & 0.98 & 0.32 & 0.09 & 20.46 & 2.00 \\
\hline & 1 & 3.22 & 2.41 & 2.96 & 1.23 & 2.34 & 0.65 & 1.01 & 0.64 & 0.26 & 0.07 & 14.79 & 2.14 \\
\hline & 2 & 3.10 & 2.01 & 2.50 & 1.13 & 2.31 & 0.52 & 0.80 & 0.61 & 0.20 & 0.00 & 13.18 & 2.11 \\
\hline & 3 & 3.39 & 1.96 & 2.57 & 1.06 & 2.50 & 0.56 & 0.64 & 0.69 & 0.25 & 0.00 & 13.62 & 2.10 \\
\hline & 4 & 3.09 & 1.94 & 2.54 & 1.01 & 2.13 & 0.60 & 0.86 & 0.61 & 0.23 & 0.00 & 13.01 & 2.10 \\
\hline & 5 & 3.31 & 2.06 & 2.63 & 0.90 & 2.35 & 0.59 & 0.76 & 0.67 & 0.25 & 0.00 & 13.52 & 2.09 \\
\hline & 6 & 3.26 & 2.35 & 2.98 & 1.23 & 2.63 & 0.60 & 0.76 & 0.74 & 0.26 & 0.00 & 14.81 & 2.13 \\
\hline & 7 & 4.85 & 3.46 & 4.33 & 1.88 & 3.68 & 0.79 & 1.28 & 1.02 & 0.34 & 0.09 & 21.72 & 2.17 \\
\hline & 8 & 2.47 & 1.27 & 1.87 & 0.81 & 1.77 & 0.46 & 0.63 & 0.54 & 0.18 & 0.00 & 10.00 & 1.94 \\
\hline & 9 & 3.82 & 2.44 & 3.42 & 1.31 & 3.34 & 0.73 & 1.00 & 0.93 & 0.31 & 0.07 & 17.37 & 1.86 \\
\hline & Cor & - & - & - & - & - & - & - & - & - & - & - & $-0.67^{*}$ \\
\hline
\end{tabular}

Cor, correlation significance probability.

1) 0 , control; 1-3, inorganic germanium $20 \mathrm{~g} / \mathrm{kan}, 1-3$ input times; 4-6, inorganic germanium $40 \mathrm{~g} / \mathrm{kan}, 1-3$ input times; 7-9, inorganic germanium $20 \mathrm{~g} / \mathrm{kan}, 1-3$ input times (kan, plantation unit area [180x90 cm] of Panax ginseng C. A. Meyer).

2) Sum of protopanaxadiol saponins $\left(\mathrm{Rb}_{1}, \mathrm{Rb}_{2}, \mathrm{Rc}, \mathrm{Rd}, \mathrm{Rg}_{3}\right)$ /sum of protopanaxatriol saponins (Re, $\mathrm{Rf}, \mathrm{Rg}_{1}, \mathrm{Rg}_{2}, \mathrm{Rh}_{1}$ ).

*\# $p>0.05$ correlation with germanium contents of plant and soil, respectively.

treatment $(14.67 \mathrm{mg} / \mathrm{g})$ than in the control $(20.46 \mathrm{mg} /$ $\mathrm{g})$. The ratio of protopanaxadiol ginsenoside to protopanaxatriol ginsenoside in the lateral root decreased significantly with increasing germanium content in the lateral root, showing a negative correlation and correla- tion coefficient of -0.673 .

In soil containing increased nonmetallic and metallic compounds such as inorganic germanium, plants usually perceive this as stressful and increase production of secondary metabolites. In contrast, the content of gin- 
senosides, which are secondary metabolites in ginseng plants, decreased with increasing amount and frequency of germanium application in our study. Considering that ginsenosides are the most important component for the medicinal efficacy of ginseng, a decrease in their content in ginseng after soil germanium treatment may decrease its medicinal efficacy. Therefore, more detailed studies on the phenomena and mechanisms of changes in the ginsenoside content of ginseng after soil germanium treatment are required.

\section{REFERENCES}

1. Goodman S. Therapeutic effects of organic germanium. Med Hypotheses 1988;26:207-215.

2. Arimori S, Watanabe K, Yoshida M, Magao T. Effect of Ge-132 as immuno-modulator. In: Immunomodulation by microbial products and related synthetic compounds: proceedings of an international symposium; $1981 \mathrm{Jul} 27-29$; Osaka, Japan. New York: Elsevier Science, 1982. p. 8-9.

3. Lee ST, Lee YH, Lee HJ, Cho JS, Heo JS. Germanium contents of soil and crops in Gyeongnam province. Korean J Environ Agric 2005;24:34-39.

4. Conner JJ, Shacklette HT. Background geochemistry of some rocks, soils, plants, and vegetables in the conterminous United States. Washington, DC: U.S. Government Printing Office, 1975.

5. Yang LL, Zhang DQ. Direct determination of germanium in botanical samples by graphite furnace atomic absorption spectrometry with palladium-zirconium as chemical modifier. Talanta 2002;56:1123-1129.

6. Jeong SI, Han WS. Germanium (IV) content in the Korean Angelica keiskei Koidz. Korean J Med Crop Sci 1999;7:11-15.

7. Kim JS, Kang TB, Lee HK. Extraction of organic germanium compound from garlic. Sangmyung Univ. Inst Nat Sci Ann Rep 2004;12:1-18.

8. Schroeder HA, Balassa JJ. Arsenic, germanium, tin and vanadium in mice: effects on growth, survival and tissue levels. J Nutr 1967;92:245-252.

9. Lee ST, Lee YH, Choi YJ, Lee SD, Lee CH, Heo JS. Growth characteristics and germanium absorption of rice plant with different germanium concentrations in soil. Korean J Environ Agric 2005;24:40-44.

10. Lee GP, Park HS, Won JH, Park KW. Effect of $\mathrm{GeO}_{2}$ concentration on hydroponically-grown lettuce (Lactuca sativa). J Korean Soc Hortic Sci 2005;46:113-118.

11. Han SS, Rim YS, Jeong JH. Growth characteristics and germanium absorption of soybean sprout cultured with aqueous solution of organogermanium. Agric Chem Biotechnol 1996;39:39-43.

12. Yun HK, Zhang CH, Seo TC, Huang HZ. Development of techniques for the production of selenium and germaniumenriched Chinese cabbage and pepper. J Bio-Environ Control 2007;16:180-185.

13. Chang EJ, Oh HI. Effects of addition of inorganic germanium, $\mathrm{GeO}_{2}$ on the growth, germanium and saponin contents of ginseng adventitious root in submerged culture. J Ginseng Res 2005;29:145-151.

14. National Institute of Agricultural Science and Technology. Analysis of soil and plants. Suwon: Rural Development Administration, 2000.

15. The Korean Society for Ginseng. Analysis of Korean ginseng components. Seoul: The Korean Society for Ginseng, 2008.

16. Jeollabuk-do Agricultural Research \& Extension Services. Studies on improvement of functional components in watermelon. Suwon: Rural Development Administration, 2008.

17. Kim BY, Jung BK, Choi JW, Yun ES, Choi S. Heavy metals in paddy soil of Korea. Korean J Soil Sci Fertil 1995;28:295-300.

18. Klapcinska B, Chmielowski J. Binding of germanium to Pseudomonas putida cells. Appl Environ Microbiol 1986; 51:1144-1147.

19. Marczynski B. Carcinogenesis as the result of the deficiency of some essential trace elements. Med Hypotheses 1988; 26:239-249. 